\title{
Bamber przez duże „B”. Recenzja wystawy Ty Bambrze prezentowanej w Muzeum Etnograficznym, Oddziale Muzeum Narodowego w Poznaniu
}

Kiedy pod koniec XVII wieku w wyniszczonym wojnami Poznaniu zjawiła się pierwsza grupa osadników z niemieckiej Frankonii, nikt nie mógł przypuszczać, w jaki sposób wpiszą się oni w krajobraz kulturowy i społeczny miasta - i że to wydarzenie historyczne okaże się sukcesem, stanowiącym o tożsamości miasta. Pierwsza grupa przybyłych osadników liczyła ok. 60 osób, zasiedlili oni podpoznańską wieś Luboń, a świadectwem ich przybycia jest jedyny zachowany dokument lokacyjny datowany na 1 sierpnia 1719 [Paradowska 2013: 63]. Kolejne fale migrantów — w większości rolników i ogrodników, ale i rzemieślników, przybywały do Poznania w latach 1730-1753 [Szczepaniak-Kroll 2019: 43]. Zamieszkali na terenie ówczesnych wsi okalających miasto - Dębiec, Bonin, Rataje, Wilda, Jeżyce, Górczyn, Czapury. I tak powoli z bamberczyków stawali się poznaniakami [Szczepaniak-Kroll 2029: 42], pielęgnując pamięć o tym skąd przybyli i zachowując swoją tożsamość, która z etnicznej przekształciła się w kulturową. Szybko wrośli w tkankę miasta, przyczyniając się do jego rozwoju — budowali okazałe kamienice, fundowali kapliczki, przekazywali wysokie datki na budowę kościołów, zakładali przedsiębiorstwa i warsztaty rzemieślnicze oraz prowadzili duże gospodarstwa rolne i ogrodnicze. W okresie Kulturkapmfu manifestowali swoją polską tożsamość poprzez pełnienie 
ważnych funkcji społecznych, naukowych i kulturalnych; członkowie rodzin bamberskich brali aktywny udział w Powstaniu Wielkopolskim, wspólnie walcząc jako poznaniacy i Wielkopolanie o niepodległość kraju, który wybrali [Paradowska 2013: 179-181].

Najtrudniejszy okres w życiu tej społeczności to czasy II wojny światowej niemieccy okupanci, którzy — jak pisała Maria Paradowska: „wywierali silny nacisk na podpisywanie przez nich niemieckiej listy narodowej, a niekiedy wbrew ich woli wpisywali na nią, pragnąc "przywrócić» potomków Bambrów do narodu, z którego się wywodzili, a z którym jako Polacy zupełnie się nie identyfikowali" [Paradowska 2013: 181]. Takie działania przyniosły długofalowe skutki w postaci powojennego ukrywania bamberskiego pochodzenia. Z tymi działaniami wiąże się także funkcjonowanie pejoratywnego określenia „bamber” funkcjonującego na obszarze nie tylko Poznania, ale też całej Wielkopolski. Jest ono pogardliwym określeniem wieśniaka i prostaka, ale i oznacza po prostu bogatego gospodarza [Sierociuk 2019: 45].

Renesans kultury bamberskiej i powrót do korzeni kulturowych oraz zainteresowanie własną historią pojawiło się w latach 90. XX wieku, kiedy to w 1996 roku powstało Towarzystwo Bambrów Poznańskich. W swoich szeregach skupiało tych wywodzących się z rodów bamberskich, jak i miłośników tej części kultury Poznania. Inicjatorką jego powołania była prof. Maria Paradowska, która stała się animatorką kultury bamberskiej, doprowadzając w 2003 roku do otwarcia Muzeum Bambrów Poznańskich [Paradowska 2013: 207-218; Brzezińska 2019: 193-194; Szczapaniak-Kroll, Szymoszyn: 2019, 212-215, 218]. To dzięki niej dziewczynki i kobiety ubrane w odświętne stroje bamberskie zaczęły pojawiać się na procesjach Bożego Ciała oraz na ważnych uroczystościach miejskich. Co roku też w każdą pierwszą sobotę sierpnia na poznańskim Starym Rynku obok studzienki z figurą Bamberki [Minksztym 2015: 43-45] odbywa się Święto Bamberskie na pamiątkę przybycia pierwszych osadników. Dwie kultury - polska (poznańska) i bamberska od 300 lat są ze sobą nierozerwalnie splecione [Żarczyńska 2019: 6-8], a w 2019 roku w Poznaniu uroczyście obchodzono Rok Bambrów Poznańskich — honorując tym samym kilkuwiekowe dobre sąsiedztwo i wspólną pracę na rzecz rozwoju miasta [Stanowisko...: 2019]. W jubileuszowym roku w Poznaniu wiele instytucji, organizacji i osób indywidualnych organizowało wydarzenia naukowe, kulturalne i artystyczne związane z tradycjami bamberskimi. Jedną z nich było poznańskie 
Muzeum Etnograficzne Oddział Muzeum Narodowego w Poznaniu (dalej: Muzeum Etnograficzne) ${ }^{1}$, które swoim odbiorcom postanowiło zadać pytanie: „A Ty Gościu/Czytelniku/Widzu — czy znasz własne korzenie? A może też jesteś Bambrem?” [Skibińska 2019: 18].

Największy zbiór przedmiotów zgromadzonych w poznańskim Muzeum Etnograficznym związanych z Bambrami stanowią elementy kobiecego stroju, w tym kaftany kobiece w wyrazistych kolorach - amarantowym, granatowym, turkusowym i zielonym. Stąd właśnie pomysł na to, by dominującym kolorem na wystawie ${ }^{2}$, na tle którego toczy się opowieść o osadnikach — był kolor zielony [Wywiad...: 2020]. Wystawa zaproponowana przez poznańskich muzealników ma być drogą, podczas której widz towarzyszy osadnikom od momentu, kiedy ci pojawili się w Poznaniu i jego okolicach, aż po czasy współczesne. Droga posiada siedem przystanków, z których każdy opowiada o innym etapie rozwoju kultury bamberskiej i jej miejscu w kulturze miasta, o sferze prywatnej i osobistej oraz o tożsamości grupowej. Prowokacyjny tytuł wystawy — „Ty Bambrze!” — w zamierzeniu jej autorów miał stanowić rodzaj rękawicy rzuconej w stronę widza, poprzez odwołanie się do wspominanego wyżej pejoratywnego określenia. Bamber pisane przez „małe b” to określenie kogoś gorszego, natomiast pisane przez „duże B” ma określać tych, którzy osiągnęli sukces, są gospodarni, pracowici, bogaci i dumni. Zatem od razu widz zostaje skonfrontowany ze stereotypem, który łatwo ulega zniwelowaniu po zapoznaniu się z długą i skomplikowaną drogą do sukcesu, jakim niewątpliwie jest trzystuletnie trwanie tradycji bamberskich. Zamierzeniem Muzeum Etnograficznego było, aby wystawa miała swoich widzów: „(...) skłaniać do refleksji nad relacjami my — oni, swój - obcy, na przykładzie relacji sąsiedzkich pomiędzy Bambrami i nie-Bambrami. Jest pomyślana jako opowieść o Bambrach obserwowanych z zewnątrz — <<okiem sąsiada >> i poprzez pryzmat utartych obiegowych

\footnotetext{
${ }^{1}$ Artefakty związane z Bambrami znajdują się w zbiorach oddziałów Muzeum Narodowego w Poznaniu - Muzeum Etnograficznym i Muzeum Historii Miasta Poznania oraz w Muzeum Bambrów Poznańskich [Mrugalska-Banaszek 2019: 165-185]. Od 1911 roku w Poznaniu gromadzone były i dokumentowane bamberskie ubiory codzienne i stroje odświętne, początkowo przez Helenę i Wiesławę Cichowicz, później przez dr Zofię Grodecką [Minksztym 2015: 18-22; Minksztym 2018: 2013]. Dzięki temu poznańskie Muzeum Etnograficzne dysponuje jedyną tak bogatą i różnorodną kolekcją, stale wzbogacaną i uzupełnianą w toku prowadzonych badań. Warto podkreślić, że wszystkie prezentowane na recenzowanej wystawie eksponaty są związane z rodzinami bamberskimi [Wywiad...: 2020].

${ }^{2}$ Autorką aranżacji plastycznej wystawy jest Joanna Lewandowska.
} 
opinii, według których przypisywano im cechy powszechnie uznane jako typowe dla Bambra” [Skibińska 2019: 5].

Pierwszym słowem wprowadzającym widzów w świat kultury bamberskiej jest „Obcość” oraz krótka informacja „Bambrzy przybyli do Poznania z terenu Niemiec w latach 1719-1753 przynosząc swoja kulturę i język [Skibińska 2019: 20]. Wyglądali inaczej, mówili inaczej — ta inność pokazana jest na planszy datowanej na 1911 rok, ukazującej 9 fotografii — na trzech z nich widnieje Bamberka w tradycyjnym stroju (w różnych ujęciach), na pozostałych siedmiu utrwalony został wizerunek Cyganki. Fotografie zostały zestawione w ten sposób na jednej karcie przez archiwistę Keiser Friedrich Museum w Poznaniu i miały pokazywać innych, odmiennych od większości, inaczej wyglądających, wyróżniających się w sposób wyraźny spośród pozostałych mieszkańców miasta. Bamberki w swoich charakterystycznych ubiorach pojawiały się w przestrzeni Poznania - nie tylko na uroczystościach kościelnych, ale i podczas sprzedawania na miejskich rynkach wyhodowanych płodów rolnych, podczas robienia zakupów. Stąd jednym z prezentowanych w tej części wystawy jest codzienny ubiór, którego wyróżnikiem jest czepek-budka wykonany ze słomki ryżowej oraz trapezowy koszyczek. Kolejnym przymiotnikiem określającym Bambrów to „Katolik” wraz z doprecyzowaniem, że „Wyznawana religia ułatwiła Bambrom zadomowienie się w Poznaniu” [Skibińska 2019: 28]. Pozostałością materialną we współczesnym krajobrazie miasta są liczne kapliczki - nadal zadbane; na wystawie prezentowane są figury pochodzące z nieistniejącej już kapliczki przydomowej rodziny Hirschów z Winiar — św. Idzi oraz św. Józef. Przywiązanie do wiary katolickiej związane było także z aktywnym uczestnictwem w procesjach Bożego Ciała, podczas którego Bamberki ubrane w uroczyste stroje nosiły feretrony, figury i święte obrazy - co zostało udokumentowane na licznych fotografiach, obrazach i pocztówkach. Przywiązanie do ziemi oraz dobry sposób gospodarowania swoimi dobrami pokazuje kolejna część zatytułowana „Gospodarny”, przywołująca także cechy społeczności bamberskiej: „Bambrzy dali się poznać jako pracowici, uczciwi i oszczędni” [Skibińska 2019: 48]. Owa gospodarność przejawiała się nie tylko w zarządzaniu gospodarstwami, ale w takich drobnych czynnościach jak dbałość o ubiór i strój (cerowanie, naprawianie, przerabianie poszczególnych elementów garderoby). Ilustrować to mają także prezentowane na ekspozycji popękane naczynia 
(garnek gliniany i talerz) zabezpieczone drutem w taki sposób, by nadal mogły być użytkowane. Sukces gospodarczy związany był także z silnymi więzami rodzinnymi oraz wzajemnym wspieraniem się i swoich rodzin. Stąd autorzy wystawy uznali, że kolejny przymiotnik „Rodzinny” dobrze określa grupę potomków osadników. Bambrzy — jak czytamy w opisie kolejnej części wystawy: „Dbali o więzy rodzinne zapewniające im poczucie wspólnoty i bezpieczeństwa” [Skibińska 2019: 66]. Ilustrują to ciekawe fotografie - ze ślubów i wesel, ale i te uwieczniające grupy rodzin pozujące w swoich ogrodach i na gankach przed domami. Widoczni są na nich ludzie zadowoleni, dumni, ubrani w drogie stroje, co świadczyło o ich wysokim statusie ekonomicznym. Zarówno przedmioty codziennego użytku, jak i te ważne (np. święte obrazy) przekazywane były w rodzinach z pokolenia na pokolenie [Wywiad...: 2020]. Oglądając umieszczony w gablocie odświętny strój bamberki wykonany z niebieskiego jedwabiu „lyońskiego” oraz towarzyszące mu misternie wykonane akcesoria (szkatułkę, wyszywany koralikami portfelik oraz zestaw przyborów do szycia i haftu), nie sposób się nie zgodzić z autorami wystawy, że najwłaściwszym przymiotnikiem w tym miejscu jest „Zamożny”, co doprecyzowuje opis: „Ze względu na duże gospodarstwa i kosztowne ubiory postrzegano ich jako bogatych” [Skibińska 2019: 74]. Emanacją owej zamożności pozostaje kobiecy ubiór bamberski, a właściwie jego „dolne” elementy, czyli trzy watówki, halka, spódnica spodnia i spódnica wierzchnia wykonana z kremowej tkaniny w drobny i subtelny wzór różyczek ujętych w bukieciki. Ta część wystawy „ «Ubrany jak Bamber»” wraz z opisem tłumaczącym, że: „Obfity i barwny strój Bamberek kontrastował z modą miejską XIX i początku XX wieku” [Skibińska 2019: 92] jest miejscem, w którym zwiedzający często wykonują sobie zdjęcia. Jest to sprytnym zabiegiem, gdyż w tym momencie widzowie przenoszeni są do czasów współczesnych, czyli do miasta, w którym nikt nie wyobraża sobie Starego Rynku bez pomnika Bambereczki, pamiątek z miasta bez bamberskich motywów i pierwszej niedzieli sierpnia bez tradycyjnego spotkania przy „sznece z glancem”3 serwowanej z okazji świętowania przybycia pierwszych bamberskich osadników. Wystawę zamyka część zatytułowana „Sukces” - to jedyny rzeczownik użyty do opisu kultury bamberskiej. „Trzysta lat obecności Bambrów współtworzy charakter Poznania” [Skibińska 2019: 102] stwierdzają autorzy wystawy

${ }^{3}$ Drożdżówka polana gęstym lukrem. 
i pokazują ów sukces ${ }^{4}$ - corocznie wydawane przez Towarzystwo Bambrów Poznańskich kalendarze z Bambrami, pamiątkowe lalki w strojach bamberskich, czy wreszcie potwierdzenie z 2018 roku wpisu na Krajową listę niematerialnego dziedzictwa kulturowego zjawiska „Tradycje kulturowe Bambrów Poznańskich” [Krajowa...: 2018].

W 2019 roku kiedy cały Poznań świętował 300 lat obecności Bambrów w Poznaniu, dokonywano wielu podsumowań i zastanawiano się nad wkładem tej grupy migrantów w rozwój miasta. Poznańskie Muzeum Etnograficzne przygotowało wystawę nie tylko dlatego, że posiada największą kolekcję artefaktów związanych z rodzinami bamberskimi, ale dlatego że z antropologiczną wrażliwością i etnograficzną drobiazgowością potrafi opowiadać o nas samych, zadawać widzom trudne pytania oraz umiejętnie łączyć światy przeszłe ze światem współczesnym. Potrafiło zmierzyć nas - widzów, z własnymi przekonaniami na temat „innych”, „obcych”, „nierozpoznanych”. Jak pisał w swojej recenzji wystawy Wojciech Hildebrant: „Ty bambrze» rzucone w Poznaniu to wciąż obelga. Nie tyle co «ty żydzie» czy «ty szwabie», ale w czasach obsesyjnego dzielenia na swoich i obcych to już nie jest tylko śmieszne lokalne zawołanie” [por. Hildebrant 2019]. Świadomi tego autorzy wystawy na koniec stawiają widza przed lustrem, na którym widnieje napis: „Ty Bambrze! A czy wiesz, że co czwarty poznaniak jest potomkiem osadników spod Bambergu?” [Skibińska 2019: 109]. Intencją muzealników było to, aby każdy spoglądający w lustro mógł się zastanowić jak on sam czuje się z tym napisem nad głową, uświadamiając sobie jednocześnie, że określenie to może dotyczyć jego samego [Wywiad...: 2020].

Patrzymy więc sami na siebie — otoczeni przejawami kultury tych, którzy wybrali się w długą drogę do dalekiego Poznania; którzy są Bambrami i poznaniankami oraz poznaniakami; którzy potrafiąc zachować pamięć o swoim pochodzeniu identyfikują się z tym co w naszym mieście dzieje się współcześnie; którzy mierząc się z krzywdzącymi stereotypami nie ustawali w pracy na rzecz rozwoju miasta.

\footnotetext{
${ }^{4}$ Działalność Towarzystwa Bambrów Poznańskich została także wyróżniona przyznaniem honorowej Nagrody im. Oskara Kolberga „za zasługi dla kultury ludowej” w 2019 roku [Nagroda...: 2019].
} 

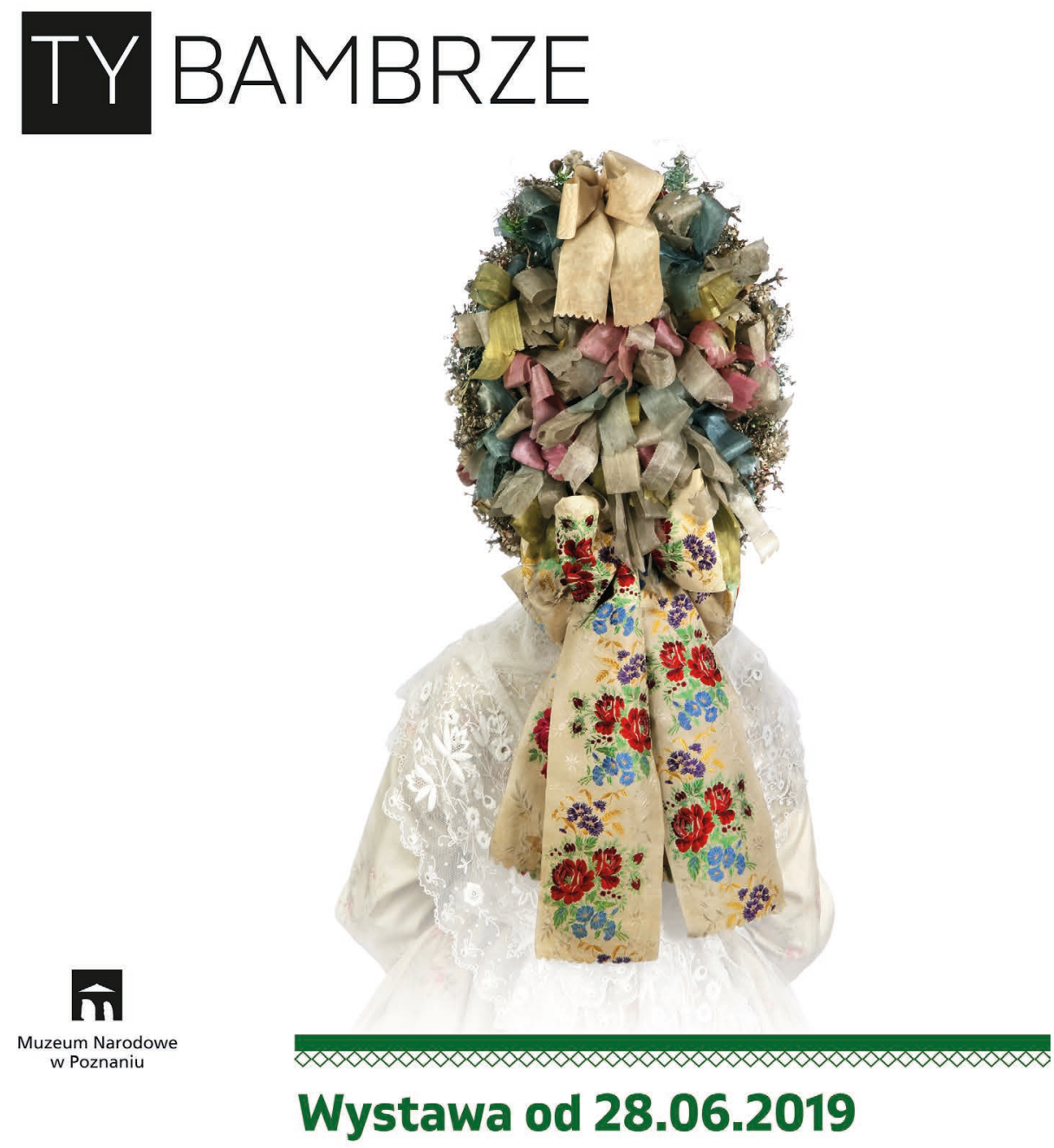

Muzeum Etnograficzne

Oddział Muzeum Narodowego w Poznaniu

wejście od ul. Mostowej 7

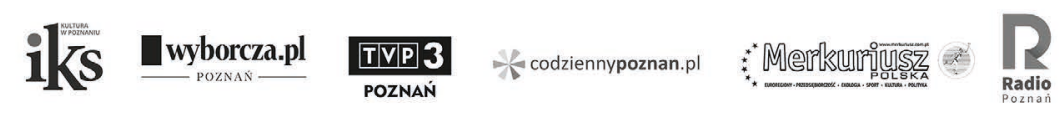

Il. 1. Projekt plakatu: Lidia Żurad, źródło: Muzeum Narodowe w Poznaniu 


\section{Bibliografia:}

\section{Brzezińska Anna Weronika}

2019: Dziedzictwo kulturowe Bambrów w przestrzeni współczesnego Poznania, [w:] 300 lat Bambrów w Poznaniu. Wkład małych wspólnot migracyjnych $w$ dziedzictwo kulturowe Polski, red. A. W. Brzezińska, A. Szczepaniak-Kroll, A. Szymoszyn, Poznań: Wydawnictwo Miejskie Posnania, Instytut Archeologii i Etnologii Polskiej Akademii Nauk.

\section{Hildebrant Wojciech}

2019: Ty bambrze - bez obrazy, „Wielkopolska. Kultura u podstaw”, 9 września 2019, w: https://kulturaupodstaw.pl/ty-bambrze-bez-obrazy-wojeciech-hildebrandt/, data odczytu: 26.05.2020.

\section{Minksztym Joanna}

2015: Strój bamberski, seria „Atlas Polskich Strojów Ludowych”, z. 47, Wrocław: Polskie Towarzystwo Ludoznawcze.

2018: W pięknym dziale strojów i haftów...” dr Zofia Grodecka oraz jej praca kolekcjonerska inaukowa w Poznańskim Muzeum Etnograficznym 1961-1986, seria „Atlas Polskich Strojów Ludowych”, z. 48, [w:] Współczesna problematyka badań nad strojami ludowymi, A. W. Brzezińska, A. Paprot-Wielopolska, M. Tymochowicz (red.), Wrocław: Polskie Towarzystwo Ludoznawcze.

\section{Mrugalska-Banaszek Magdalena}

2019: Rzeczy bamberskie w poznańskich muzeach, [w:] 300 lat Bambrów w Poznaniu. Wkład małych wspólnot migracyjnych $w$ dziedzictwo kulturowe Polski, red. A. W. Brzezińska, A. Szczepaniak-Kroll, A. Szymoszyn, Poznań: Wydawnictwo Miejskie Posnania, Instytut Archeologii i Etnologii Polskiej Akademii Nauk.

\section{Paradowska Maria}

2013: Bambrzy. Mieszkańcy dawnych wsi miasta Poznania, Poznań: Media Rodzina.

\section{Sierociuk Jerzy}

2019: Bamber — rozwój znaczeniowy wyrazu, „Kronika Miasta Poznania”, t. 2, red. Magdalena Mrugalska-Banaszak, Poznań: Wydawnictwo Miejskie Posnania.

\section{Skibińska Aneta (red.)}

2019: Ty Bambrze!, Poznań: Muzeum Narodowe w Poznaniu.

\section{Szczepaniak-Kroll Agnieszka}

2019: Bambrzy w krajobrazie Poznania, czyli o tożsamości, jej trwaniu i zmianach, [w:] 300 lat Bambrów w Poznaniu. Wkład małych wspólnot migracyjnych $w$ dziedzictwo kulturowe Polski, red. A. W. Brzezińska, A. Szczepaniak-Kroll, A. Szymoszyn, Poznań: Wydawnictwo Miejskie Posnania, Instytut Archeologii i Etnologii Polskiej Akademii Nauk.

\section{Szczepaniak-Kroll Agnieszka, Szymoszyn Anna}

2019: Profesor Maria Paradowska - inicjatorka renesansu Bambrów w krajobrazie kulturowym Poznania i propagatorka wiedzy o bambrach, [w:] 300 lat Bambrów w Poznaniu. Wkład małych wspólnot migracyjnych w dziedzictwo kulturowe Polski, red. A. W. Brzezińska, A. Szczepaniak-Kroll, A. Szymoszyn, Poznań: Wydawnictwo Miejskie Posnania, Instytut Archeologii i Etnologii Polskiej Akademii Nauk. 


\section{Żarczyńska Justyna}

2019: Co bamberskie, co polskie?, „Poznańskie Informator Kulturalny, Sportowy i Turystyczny OKS”, sierpień, nr 8 (334).

\section{Dokumenty:}

Krajowa lista niematerialnego dziedzictwa kulturowego: http://niematerialne.nid.pl/ Dziedzictwo_niematerialne/Krajowa_inwentaryzacja/Krajowa_lista_NDK/, data odczytu: 02.06.2020.

Stanowisko Nr V/44/VIII/2/2019 Rady Miasta Poznania z dnia 08-01-2019 w sprawie ustanowienia roku 2019 Rokiem Bambrów Poznańskich: https://bip.poznan.pl/bip/ uchwaly/uchwala-nr-v-44-viii-2-2019-z-dnia-2019-01-08,77795/, data odczytu: 02.06.2020.

Nagroda im. Oskara Kolberga - Towarzystwo Bambrów Poznańskich: http://www.nag rodakolberg.pl/laureaci-towarzystwo_bambrow_poznanskich, data odczytu: 02.06.2020.

\section{Strony internetowe}

Muzeum Narodowe w Poznaniu: https://mnp.art.pl/wydarzenia_i_wystawy/ty-bambrze/, data odczytu: 26.05.2020.

\section{Wywiady}

Wywiad z dr hab. Joanną Minksztym przeprowadzony w Muzeum Etnograficznym w Poznaniu, 20.05.2020, w archiwum autorki. 
